\title{
Parasitological Assessment of Some Selected Vegetables Commonly Consumed Raw in Ankpa Local Government, Kogi State North Central Nigeria
}

\author{
Joshua Idakwo ${ }^{1 *}$, Munirat Eleojo Usman ${ }^{1}$, Emmanuel Taiwo Idowu', Bashir Ala- \\ bi $\mathrm{Ali}^{3}$, and Queen Pheobe Akoh ${ }^{4}$ \\ ${ }^{1}$ Department of Animal \& Environmental Biology, Kogi State University, Anyigba, Kogi State, Nigeria. \\ ${ }^{2}$ Department of Zoology, University of Lagos, Lagos State Nigeria \\ ${ }^{3}$ Department of Plant Science and Biotechnology, Kogi State University, Anyigba, Kogi State, Nigeria. \\ ${ }^{4}$ Department of Microbiology, Kogi State University, Anyigba, Kogi State, Nigeria.
}

*Correspondence should be addressed to Joshua Idakwo: jodakwo@gmail.com

Received 18th February 2021; Revised 3rd April 2021; Accepted 17th April 2021

(C) 2021 Idakwo et al. Licensee Pan African Journal of Life Sciences an official publication of Faculty of Basic Medical Sciences, Ladoke Akintola University of Technology, Ogbomoso. This is an Open Access article distributed under the terms of the Creative commons Attribution License (https://creativecommons.org/licenses/BY/4.0), which permits unrestricted use, distribution, and reproduction in any medium, provided the original work is properly cited.

\begin{abstract}
Background: Consumption of raw vegetables without proper washing can act as a potential route of transmission of some infectious and parasitic diseases. This study determined the parasitic contamination of vegetables sold in some markets in Ankpa Local Government Area, Kogi State.

Methodology: Vegetables was purchased from selected markets in Ankpa Local Government Area, North Central of Nigeria. Two hundred and forty samples of six different vegetable types - Carrot, Spinach, Pumpkin, Tomatoes, Cucumber and Garden egg were purchased from three different markets. The vegetables were examined microscopically for the presence of parasites using standardized parasitological techniques for protozoans and helminths.
\end{abstract}

Results: Remarkable level of intestinal protozoa and helminthes contaminations of different life stages were recovered. Out of the 240 samples, 34 (14.2\%) were positive for different species of parasites. Entamoeba histolytica $15(6.3 \%)$ had the highest occurrence while Strongyloides stercoralis $(0.4 \%)$ had the least. Other parasites recovered include Hookworm eggs (2.1\%), Giardia lamblia (1.7\%), Fasciola hepatica (0.8\%), Trichuris trichiura (1.3\%), Ascaris lumbricoides $(0.8 \%)$, and Taenia spp (0.8\%). A significant difference was observed in the prevalence of the identified parasites $(\mathrm{p} \leq 0.05)$. Spinach contamination had the highest parasitic load of $20.0 \%$, while Garden egg had the least with $10.0 \%$. Prevalence of parasites varied across markets, with Ankpa main market having the highest with $15.9 \%$ compared to Afor (12.5\%) and Ukwo (10.3\%) located in the interior. No significant difference was observed among the markets and the vegetables $(\mathrm{p} \leq 0.05)$

Conclusion: Raw vegetables investigated are contaminated with pathogenic parasites. Therefore, consumers need to ensure necessary hygiene practices before consuming vegetables purchased from markets to reduce the risk of infection by parasites associated with vegetables.

Keywords: Intestinal parasites, Protozoa, Helminthes, Vegetables, Ankpa, Nigeria 


\section{INTRODUCTION}

Vegetables are a palatable food source that improve appetite and are essential for human health and wellbeing and form a major component of a healthy diet. They are highly essential for maintenance of health and prevention of diseases [1]. Vegetables are an important part of a healthy and balanced meal, providing vitamins, minerals, and phytonutrients [2]. Many vegetables are sources of protein, fat, and a proportion of vitamins, provitamins, dietary minerals, alpha and beta carotene, zea-xanthins, flavonoids, and anthocyanins. These body nutrients help reduce the risk of cardiovascular diseases such as stroke, diabetes, cancer, kidney stones, and boneloss [3]. The foliage in vegetables improves the formation of red blood cells while the vitamins in vegetables keep the eyes healthy, heals wound, aid iron absorption, promote healthy teeth and gum [4]. They also help prevent constipation, hemorrhoid, and rectal fissures $[5]$.

Some vegetables are mostly consumed raw as a salad to retain the natural taste and preserve heat-labile nutrients, while others are consumed cooked. Vegetables often consumed cooked include, leafy vegetables such as pumpkin leaves, scent leaves, and bitter leaves. Vegetables usually consumed raw include cabbage, cucumber, lettuce, and the like. However, certain vegetables can either be consumed raw or cooked. Such vegetables include carrots, garden eggs, and the like. Consuming cooked vegetables is healthy, but it is more beneficial to consume raw vegetables [6]

Despite the nutritional values of vegetables to human health, they are major carriers of infective parasites. They act as a passive vehicle for the transmission of helminths through the fecal-oral route [7]. The consumption of raw vegetables without proper washing is an important route in the transmission of parasitic diseases. Intestinal parasites associated with raw vegetables belong to protozoan, cestodes, nematodes, and trematodes [8]. The incidence and distribution of human intestinal parasites are traced to the consumption of raw vegetables, which play a major role in transmitting food-borne parasitic diseases [9].

The processes involved in vegetable cultivation, harvesting, transportation, and processing have made them a potential source of human infections due to their contamination by disease pathogens of different kinds $[3,10]$. Vegetables can be contaminated while growing in fields by organic fertilizer or contaminated irrigation water or during harvesting, processing, distribution, sales, and consumption [11]. Fresh vegetables are notable hosts of several epiphytic microorganisms, which are mostly nonpathogenic. However, during the movement of the produce from the field to consumers especially in the open field cultivation, fresh vegetables are exposed to environmental conditions or factors that enhance the introduction of pathogenic microorganisms and parasites $[12,13,14]$.

Many outbreaks of protozoan infections in humans have been linked to raw fruits and vegetables. In Nigeria, approximately 55 million people are infected with ascariasis, 38 million with hookworm infection, while 34 million are infected with trichuriasis [15]. Although few studies have already reported that vegetables grown and marketed in some parts of Nigeria present poor parasitological quality $[12,16]$, there are no data in Ankpa Local Government,. Therefore, the present study assessed the presence and intensity of parasite contaminants in commercial vegetables in different markets in Ankpa Local Government.

\section{METHODS AND MATERIALS}

\subsection{Study Area}

This study was conducted in Ankpa Local Government, Kogi state, Nigeria. Ankpa is situated in the Middle East of Nigeria with Longitude $7^{\circ} 30^{\prime} 0^{\prime \prime}-7^{\circ} 50^{\prime} 0^{\prime \prime} \mathrm{E}$ and Latitude $7^{\circ} 20^{\prime} 0^{\prime \prime}-7^{\circ} 30^{\prime} 0^{\prime \prime} \mathrm{N}$. It has an area of $1,200 \mathrm{~km}^{2}$ and a population of 359,300 based on the 2016 National Population census (17) (Fig. 1). Ankpa has a tropical climate with an average temperature of $25.50 \mathrm{C}$. About $1392 \mathrm{~mm}$ of precipitation falls annually. The warmest month of the year is March, with a temperature of $290 \mathrm{C}$ to $300 \mathrm{C}$ and a lowest annual temperature of $23.90 \mathrm{C}$ occurs in August. The majority of the inhabitants of the Area are peasant farmers and petty traders with low economic status.

\subsection{Study Design}

This study design was randomized, involving a random selection of 240 samples of six vegetable species purchased from different vendors in three selected markets in Ankpa Local Government Area, Kogi State, which were examined for the presence of parasites.

\subsection{Sample Collection}

Samples were randomly purchased from different vendors within Ankpa township market, Afor and Ukwo 




Figure 1: Map of the Study Area

markets strategically located and known for a high level of commercial activities weekly. Forty samples each of Daucus carota (carrot), Cucumis sativus (cucumber), Solanum macrocarpon (garden egg), Telfairi occidentalis (pumpkin), Solanum lycopersicum (Tomato) and spinacia oleracea (Spinach) were purchased and transported to the Microbiology laboratory of Kogi State University, Anyigba each in a well-labeled sterile polythene bags. Taxonomic identification of the various vegetable types was done by plant taxonomists in the Department of Plant and Biotechnology, Kogi State University, Anyigba, which were deposited in the Departmental herbarium with specific localized identification numbers.

\subsection{Laboratory Analysis}

Vegetable samples were removed from the polythene bags with gloved hands and placed on well-sterilized platforms. Each of the samples was carefully examined macroscopically for the presence of segments of cestodes and adult nematodes. Three hundred grams of each sample was weighed and placed in a clean bowl containing $600 \mathrm{ml}$ of sterile physiological normal saline $(0.95 / \mathrm{NaCl})$ to detach the parasitic stages (ova, larvae, cysts, and oocysts) of helminths from the surface of the samples. The samples were washed thoroughly, and the water was left overnight for proper sedimentation, and then the supernatant was decanted. The deposit was resuspended with $10 \%$ formal saline and centrifuged at 4000rmp for 12 minutes, the supernatant was decanted carefully without shaking, and the residue was collected. A drop of the res- idue was placed on a clean and grease-free slide with a drop of iodine to enhance the proper view of the parasites. The slide was covered with a coverslip avoiding air bubbles and over floating and examined for parasitic stages under the microscope using the X10 and X40 objective lenses [18].

\subsection{Data Analysis}

Data obtained were subjected to descriptive statistics, and chi-square tests were performed for the various categories of infection using Statistical Package for Social Sciences (SPSS) version 21.0 at $\mathrm{p} \leq 0.05$ level of significance.

\section{RESULTS}

Out of the 240 samples of the six vegetable types, 34 were positive for at least one intestinal parasite with a percentage of $14.20 \%$. The parasites recorded in this study include Ascaris lumbricoides, Hookworm, Entamoeba histolytica, Giardia lamblia, Fasciola hepatica, Trichuris trichiura, Taeniaspp, and Strongyloides stercoralis. The results of parasitic contamination of vegetables are shown in Table 1.The parasite prevalence in Carrot, Spinach, Pumpkin, Tomatoes, Cucumber, Garden egg sample groups are $12.50 \%, 20.00 \%, 15.00 \%$, $15.00 \%, 12.50 \%$, and $10.00 \%$, respectively. Table 3 shows various parasite prevalence for each market. The most prevalent parasite was Entamoeba histolytica with a prevalence of 15 (6.30\%), while the least was Strongyloides stercoralis larva with a prevalence of $1(0.40 \%)$. These findings imply that the presence of parasites varies with the type of vegetable, with Spinach having the highest prevalence $(20.00 \%)$, while Garden egg had the least prevalence of $10.00 \%$. There was no significant difference between parasites present and vegetable type $(\mathrm{p}>0.05)$. Parasitic contamination of vegetables with respect to markets is shown in Table 5 with Ankpa main market recordingthe highest prevalence $(18.89 \%)$, followed by Afor market (12.50\%), while the least was Ukwo market with a prevalence of $10.25 \%$.

\section{DISCUSSION}

The result of this study shows the presence of eight different species of parasites in the selected vegetables. They include Hookworm egg, Entamoeba histolytica cyst, Giardia lamblia cyst, Fasciola hepatica egg, Trichuris trichiura egg, Ascaris lumbricoides egg, Taenia spp 
Table 1: Parasitic Contamination of Vegetables with Respect to Vegetable Type

\begin{tabular}{|c|c|c|c|c|c|c|c|c|}
\hline & $\begin{array}{l}\text { Carrot } \\
(n=40)\end{array}$ & $\begin{array}{l}\text { Cucumber } \\
(n=40)\end{array}$ & $\begin{array}{l}\text { Spinach } \\
(n=40)\end{array}$ & $\begin{array}{l}\text { Pumpkin } \\
(n=40)\end{array}$ & $\begin{array}{l}\text { Garden } \\
\text { egg } \\
(n=40)\end{array}$ & $\begin{array}{l}\text { Tomatoes } \\
(n=40)\end{array}$ & $\begin{array}{l}\text { Total } \\
(n=240)\end{array}$ & p-value \\
\hline Hookworms & $1(2.50)$ & $2 .(5.00)$ & 0 & 0 & 0 & $2(5.00)$ & $5(2.10)$ & 0.314 \\
\hline E. histolytica & $2(5.00)$ & $2(5.00)$ & $3(7.50)$ & $3(7.50)$ & $2(5.00)$ & $3(7.50)$ & $15(6.30)$ & 0.986 \\
\hline Giardia lamblia & $1(2.50)$ & 0 & $2(5.00)$ & 0 & 0 & $1(2.50)$ & $4(1.70)$ & 0.406 \\
\hline Fasciola hepatica & 0 & 0 & $1(2.50)$ & $1(2.50)$ & 0 & 0 & $2(0.80)$ & 0.545 \\
\hline Trichuris trichiura & 0 & 0 & $2(5.00)$ & $1(2.50)$ & 0 & 0 & $3(1.30)$ & 0.214 \\
\hline Ascaris lumbricoides & 0 & $1(2.50)$ & 0 & 0 & $1(2.50)$ & 0 & $2(0.80)$ & 0.545 \\
\hline Strongyloides stercoralis & 0 & 0 & 0 & $1(2.50)$ & 0 & 0 & $1(0.40)$ & 0.413 \\
\hline Taenia spp & $1(2.50)$ & 0 & 0 & 0 & $1(2.50)$ & 0 & $2(0.80)$ & 0.545 \\
\hline
\end{tabular}

$\mathrm{n}=$ number of vegetable examined

Table 2: Parasite Prevalence for Various Vegetables

\begin{tabular}{lllll}
\hline Vegetables & Number & Number & Preva- & p- value \\
\hline Carrot & 40 & 5 & 12.50 & 0.238 \\
Spinach & 40 & 8 & 20.00 & \\
Pumpkin & 40 & 6 & 15.00 & \\
Tomatoes & 40 & 6 & 15.00 & \\
Cucumber & 40 & 5 & 12.50 & \\
Garden egg & 40 & 4 & 10.00 & \\
& 240 & 34 & 14.20 & \\
\hline
\end{tabular}

Table 3: Various Parasites' Prevalence for Each Market.



$\mathrm{n}=$ number of vegetables sampled per market 
Table 4: Cumulative Parasites Prevalence for the Market Locations

\begin{tabular}{lllll}
\hline Parasites & Number of sample & Number positive & Prevalence (\%) & P-value \\
\hline Hookworm & 240 & 5 & 2.10 & $0.000^{*}$ \\
Entamoeba histolytica & 240 & 15 & 6.30 & 1.70 \\
Gardia lamblia & 240 & 4 & 0.80 \\
Fasciola hepatica & 240 & 2 & 1.30 \\
Trichuris trichiura & 240 & 3 & 0.80 \\
Ascaris lumbricoides & 240 & 2 & 0.80 \\
Strongyloides stercoralis & 240 & 2 & 0.40 \\
Taenia spp & 240 & 1 & 1.80 & \\
& & 34 & \\
\hline
\end{tabular}

$*=$ significant at $\mathrm{p} \leq 0.05$.

Table 5: Parasitic Contamination of Vegetables by Market locations

\begin{tabular}{lllll}
\hline Markets & $\begin{array}{l}\text { Numberof } \\
\text { vegetables } \\
\text { screened }\end{array}$ & $\begin{array}{l}\text { Number } \\
\text { contam- } \\
\text { inated }\end{array}$ & $\begin{array}{l}\text { Preva- } \\
\text { lence (\%) }\end{array}$ & $\begin{array}{l}\text { p- } \\
\text { value }\end{array}$ \\
\hline $\begin{array}{l}\text { Ankpa main } \\
\text { market }\end{array}$ & 90 & 17 & 15.89 & 0.797 \\
Afor Market & 72 & 9 & 12.50 & \\
Ukwo Market & 78 & 8 & 10.25 & \\
Total & $\mathbf{2 4 0}$ & $\mathbf{3 4}$ & $\mathbf{1 4 . 2 0}$ & \\
\hline
\end{tabular}

other parts of the country where a low prevalence of $E$. histolytics was reported [16,21]. The prevalence of Strongyloides stercoralis $(0.4 \%)$ was the least among other parasites identified in this study, which does not agree with an earlier study [16]. These differences might be due to different climatic conditions and variations in geographical locations of the study area. However, in other studies across the globe, occurrence of Strongyloides stercoralis larva was traced to its free living nature and does not always require a host for its proliferation, in addition to its parasitic mode of life [22].

The overall low prevalence (14.2\%) reported in this study is not consistent with the findings of Damen et al. (2007) [23] and Said (2012) [6] who recorded a higher prevalence of $36.0 \%$ and $31.7 \%$ in Jos, Nigeria and Alexander, Egypt respectively. However, the total parasite prevalence in this study agrees with the reports from Kaduna [24] and Zaria [25] where low prevalence was reported. This could be attributed to poor hygiene and sanitary handling of vegetables, poor transport and packaging of vegetables, waste and contaminated water for irrigation, washing of vegetables, and other conditions of cultiva- tions. Although the investigation of the present study revealed parasite contamination of the vegetables at different rates, it is statistically not significant $(\mathrm{p}>0.05)$ which is consistent with previous report [26].

The findings of this present study show variations across market locations. The prevalence at Ankpa main market $17(15.89 \%)$ is not significantly higher than that of Afor market $9(12.50 \%)$ and Ukwo market $8(10.25 \%)$. These findings agree with those of Shinkafi et al. (2016) [27]; Akoma et al. (2017) [19], and Iyaji and Agahiu (2016) [28], who reported that there were significant differences in the rate of contamination of vegetables sampled from different markets in Katsina, Lokoja, and Anyigba respectively.

The differences in the contamination rates observed in the three locations could be because vegetables from Afor and Ukwo markets found in the interiors were directly from the farm with minimal contact with humans and other contaminants. Ankpa main market with the highest prevalence of parasite contamination might probably be due to poor hygiene and handling of the vegetables, poor means of transportation and packaging of the vegetables, and the type of water used for washing the vegetables before selling in the market. Similar findings were reported by other researchers who also attributed the prevalence to the level of education of the vegetable vendors, among others [29].

Spinach recorded the highest parasite contamination while Garden egg had the lowest prevalence probably because Spinach is a leafy vegetable with a wide surface area for contacts and attachment of parasites infective 
stages.

The small sample size and unavailability of information on the background and personal hygiene of the vegetable markers may have been a major contributing factor to the results obtained in this study.

The findings of this present study have revealed that vegetables consumed raw in Ankpa Local Government are carriers of infective parasites which cause various diseases in humans and domestic animals. A single vegetable species can be contaminated by multiple parasites and vegetables that have passed through various forms of transportation and handled by different vendors tend to have high parasitic contamination than those supplied by farmers directly to the market. This indicates that humans are always at risk of infection, especially as vegetables are essentials in the diet of people of all ages. The importance of vegetables in the diet cannot be overemphasized. Therefore, consumers need to thoroughly wash all fresh vegetables purchased from the market using clean water and salt before consumption to reduce the risk of infection by parasites associated with vegetables.

\section{Acknowledgments}

We acknowledge the Department of Microbiology, Kogi State University, Anyigba for providing the laboratory space for parasitological examinations. We also appreciate the laboratory technologists for their technical assistance.

\section{Declarations}

The authors declare that there is no conflict of interest.

\section{Authors' contributions}

JI: conceived and designed the study, contributed to data and analysis and wrote the paper. MEU: Collected samples from the field, contributed to manuscript writing. ETI: Reviewed the Manuscript. BAA: Identify the vegetables. QPA: Carry out the microbiological analysis and parasite identification

\section{References}

1. Sunil B, Thomas DR, Latha C and Shameem H. Assessment of parasitic contamination of raw vegetables in mannuthy, Kerala, India. Veterinary World. 2014; 7(4): 253256.

2. Losio M, Pavoni E, Bilei S, Bertasi B, Bove D, Capuano F, Farneti S, Blasi G, Comin D, Cardamone C. Microbiological survey of raw and ready to eat leafy green vegetables marketed in Italy. International journal of food Microbiology. 2015;210:88-91.
3. Alade GO, Alade TO and Adewugbhyi IK. Prevalence of Intestinal parasites on vegetables sold in Illorin, Kwara, Nigeria. American Eurasian Journal of Agriculture and Environmental science. 2013; 13 (9):1275-1282.

4. Fagbenro MT, Mogaji HO, Oluwole AS, Adeniran AA, Alabi OM and Ekpo UF. Prevalence of parasites found on vegetables and perception of retailers and consumers about contamination in Abeokuta, Ogun State, Nigeria.Clinical Microbiology and case report. 2016; 2(1):2530

5. Duedu OK, Yarnie EA, Tetteh-Quarcoo PB, Attah SK, Donkor ES and Ayeh-Kumi PF. A comparative survey of the prevalence of human parasites found in fresh vegetables sold in supermarkets and open-aired markets markets in Accra,Ghana. Biomedical Central Research Notes. 2014;7:836-842.

6. Said DES. Detection of parasites in commonly consumed raw vegetables. Alexandria Journal of medicine. 2012; 48:345-352.

7. Beiromvard M, Aklaghi L, Massom SH, Meamer, AR, Motevalian A, Oormazdi H and Razmjou E. Prevalence of zoonotic intestinal parasites in domestic and stray dogs in a rural area of Iran. Preventive veterinary medicine. 2013; 109 (2):162-167.

8. Uneke CJ. Potential for Geohelminth parasite Transmission by raw fruits and vegetables in Nigeria: implication for a risk profile. Journal of Nutritional and Environmental Medicine, 2004; 16(1): 59-68

9. Abougrain AK, Nahaisi MH, Madi NS, Saied MM and Ghenghesh KS. "Parasitological contamination in salad vegetables in Tripoli-Libya, Iran Food Control. 2010; 21 (5), 760-762.

10. Alhabbal AT. The prevalence of parasitic contamination on common cold vegetables in Alqalamoun Region. International Journal of Pharmaceutical Sciences. Review Resources, 2015; 30(1):94-7.

11. Beuchat LR. Pathogenic Microorganisms associated with fresh produce. Journal of Food Protection. 1996; 59 (2):204-16.

12. Adamu NB, Adamu JY, Mohammed D. Prevalence of helminth parasites found on vegetables sold in Maiduguri, Northeastern Nigeria. Food Control, 2012; 25:23-6.

13. Gupta, SS., NayekS Garai D. Effect of waste water irrigation on vegetables in relation to bioaccumulation of heavy metals and biochemical changes. Environment Monitor Assessment, 2010; 165 (1-4): 169-77.

14. Ofor, MO, Okorie, VC, Ibeawuchi, II, Ihejirika, GO, Obilo, OP and Dialoke, SA. Microbial contaminants in fresh tomatoes wash water and food safety considerations in 
South-Eastern Nigeria. Life Science Journal,2009; 1:80-82.

15. Hotez PJ, and Kamath A. Neglected Tropical Diseases in Sub - Saharan Africa: Review of their prevalence, Distribution and Disease Burden. Neglected Tropical Disease. 2009; 3(8): 412.

16. Agbalaka P, Ejinaka O, Yakubu D, Obeta U, Jwanse R, and Dawet A. Prevalence of Parasites of Public Health Significance in Vegetables Sold in Jos Metropolis, Plateau State, Nigeria. American Journal of Public Health, 2019; 7, 48-57.

17. National Population Commission of Nigeria (2016). https://www.citypopulation.de/php/nigeria-admin.php? $\operatorname{adm} 2 \mathrm{id}=\mathrm{NGA} 023003$

18. Uga S, Hoa NTV, Noda S, Moji K, Cong L, Aoki Y, Rai SK. and Fujimaki Y. Parasite egg contamination of vegetables from a suburban market in Hanoi, Vietnam. Nepal Medical College Journal. 2009; 11:75-78.

19. Akoma ON, Gbarabe CL, Aminu RF. Parasitological Assessment of Selected Edible Fruitsand Vegetables Sold At Some Markets in Lokoja, North Central Region of Nigeria in the Context of Disease Surveillance. Microbiology and Infectious Diseases. 2017; 1(2): 1-6.

20. Leon, W, Monzoon, RB, Agnon, AA, Arco, RE, Ignaua, EJ and Santos M. Parasitic Contamination of Selected Vegetables Sold in Metropolitan, Manila, Philipines South East Asia. Journal of Public Health and Hygiene. 1992; 23:162164

21. Auta T, Bawa JA, and Suchet CM. Parasitic Contamination of Common fresh fruits and Vegetables sold in Markets within Dutsin-Ma town, Katsina State Nigeria. Journal of Advances in Biology and Biotechnology. 2017; 14(12):1-8
22. Idahosa OT. Parasitic contamination of fresh vegetables sold in Jos Markets, Global Journal of Medical Research. 2011; 11(1):20-25.

23. Damen J, Banwat E, Egah D. Allamanaj. Parasitic contamination of vegetables in Jos, Nigeria. Annals of African medicine. 2007; 6 (2): 115-118.

24. Umoh V, Okafor C, Galadima M. Contaminated by helminths of vegetables cultivated on land irrigated with urban waste water in Zaria and Kaduna, Nigeria.The Nigerian Journal of Parasitology. 2001; 22 (1\&2): 95-104.

25. Dauda MM, Medinat MO, Sabiu T. Parasitic contamination of fruits and vegetables sold at Kaduna metropolis, Nigeria. Nigerian Journal of Parasitology. 2011; 32(2): 309 $-315$

26. Uttah EC, Akwari A, Ukpong GL, Ogban E and Iboh C. Fruits and vegetables consumption attitude: The major risk factor in hookworm epidemiology in a tourist destination in Cross River, Calabar Nigeria. Transnational journal of science and Technology. 2013; 3 (9): 53-56.

27. Shinkafi BY, Zary SY, Umar F and Sani Z. Parasitic contamination of vegetables in some selected markets in Katsina, Nigeria. Entomology and Applied Science. 2016;3 (2): 17-21.

28. Iyaji FO and Agahiu EE. Contamination of helminth on fruits and vegetables sold in Ayingba, Kogi. Nigeria. Scholarly Journal of Agricultural Science. 2016; 6 (6): 195 $-199$.

29. Oranusi S., Braide W and Etinosa-Okankan OJ. Prevalence of geohelminths on selected fruits and vegetables sold in owerri, Imo. Nigeria. African Journal of food science and Technology. 2013; 4 (2): 35-43. 